\title{
UNVEILING SECRETS: RETHINKING HISTORY THROUGH DOCUMENTARY FILMS
}

\author{
Nihan Gider Işıkman \\ Asst. Prof. Dr. Baskent University, Turkey
}

\begin{abstract}
The dominating ideology determines the historiography, as well as the media narrative, created in line with dominating ideology plays an important role in consolidating the historical information. So, also cinema has a function to legitimize the dominating institutions and traditional values and to instill ideology. In this context, documentary, which, rely heavily on the truth as a genre and has the most credibility among its viewers, become an important arena for the execution of these functions. Today as the alternative narratives, that can be produced and distributed extensively with digital technology besides mainstream media narratives, small, personal narratives can be located against the grand, official and historical narratives. Film and video become an effective carrier of memory and acquire historical value as audio and video recording gaine prevalence. Thus, documentaries using these records to contribute to the social memory and make reminding against the official history, have come to an important point about historical issues. Documentaries, with the stories of individuals, so with a narrative from the private to the general, may, bring out important notes about the history, reveal secrets, raise questions about the accepted truths. Besides, the others in confrontation would have chance to hear each other's voices; testimonies strengthens the hearing; intercultural dialogue increases even it is mediated. Bearing in mind the re-presentation of the reality in the documentary narrative and subjectivity of individual expressions, new comments and information emerged within the framework of testimonies find their places in time in social memory and so may contribute to the different interpretations of the history.

Turkish - Armenian relations, with the common history, provides an efficient field of work to analyze the formation and re-formation of historical events in the social memory, the official history and the 'other' official history. Therefore, in this paper, documentaries, realized as a result of the works of institutions such as the Armenia Turkey Cinema Platform, which tell the untold stories of decades through individual stories and show way to sides to recognize each other, will be analyzed with their narrative structures and discourses to better understand the potential of documentaries to contribute to the social memory and history, as historical testimonies.
\end{abstract}

Keywords: Memory, testimony, history, documentary film, Turkey, Armenia

\section{GiRiş}

20.yüzyılla birlikte, dijital teknolojinin gelişmesi, görsel işitsel kayıt cihazlarının ucuzlayarak yaygınlık kazanması, film yapım süreçlerinin kolaylaşması ile birlikte film ve video artan bir oranda belleğin önemli araçlarından biri haline gelmiştir. Ev tipi kameralarla, amatör kayıtlarla tarihi anların, anıların kaydı mümkün olabilmektedir. Görüntünün inanılırlığı ve kanıtsalığı ile birlikte, özellikle röportajların kanıtsallığına temkinli yaklaşmanın gerekliliği söz konusuysa da, bu röportajların herhangi bir metinden daha az güvenilir olduğu anlamına gelmemektedir. Hatta yazılı bir metnin taşıyamacağı ipuçları görsellikte bulunabilmektedir. Dolayısıyla, geçmişi, özellikle de sessizliklere gömülmüş travmatik olayları gün ışığına çıkarmak, hatırlamak 
ve başa çıkmak etik ve politik bir yükümlülük olarak kabul edildiğinde, en ilginç bellek çalışmalarının bazılarının, dayatılan sessizlikler üzerine giden, cesur kişisel girişimler olarak bağımsız yönetmenlerin yaptıkları filmler olduğu görülmektedir.

Kabul edilmelidir ki hatırlandıkça, hakkında konuşuldukça, yazıya döküldükçe, görsel kayıtları tutuldukça geçmiş yorumlara tabi olmaktadır. Başka bir deyişle geçmişin farklı yeniden okumalara açık olması nedeniyle, geçmişin temsillerinin mümkün olduğu ölçüde tarihi gerçekleri ortaya çıkarmasını sağlayacak yöntemlere ihtiyaç vardır. Sinema, tür özellikleri çerçevesinde de gerçeğe en yakın duran, inanılırlık çerçevesinde de izleyici ön kabulüne sahip belgesel sinemanın bu noktada taşıdığı potansiyel çalışmanın temel eksenini oluşturmaktadır.

Tarihi olaylarla ilgili araştırma komisyonları, mahkemeler genellikle toplumsal bir bellek yaratmak üzere işleyen siyasi mekanizmalardır, siyasetten ve ideolojiden bağımsız değerlendirilemezler. Oysa film yapım ve dağıı̆ olanaklarının bağımsızlaşması ile birlikte, küçük seslerin de artık duyulabilir olması ile sinema tarihin ele alınması açısından etkili bir araç olarak değerlendirilmelidir. Tarihi uzlaşmazlıklarda birbirini anlamak için atılacak pek çok adım varken insanları birbirine yaklaştıran bir sanat olarak sinema önemlidir. Tarihi konuların kamuoyu gündemine taşınabilmesi, bilgi akışında çeşitliliğin sağlanabilmesi, toplumsal farkındalığın arttıııması ile toplumsal belleğe katkı sağlamak, böylelikle de tarihi uzlaşmazlıklarda bir uzlaşma, iyileşme ve yeniden yapılanma zemini oluşturmak mümkün olabilir. Bunun uzun, yavaş bir süreç olabileceği kabul edilerek sinemasal karşılaşmaların sürdürülebilmesiyle suskunluk çemberine hapsolmuş acıların üzerine gitmek başka acıları da görmemize, konuşarak aşmamıza yardımcı olabilir. Ancak böylelikle geçmişten geleceğe dair bir şeyler çıkarmak mümkün olabilir.

\section{BELGESEL SINEMA}

Toplumsal kanaatlerin oluşmasında, tarihi olaylarla ilgili olarak da, medyanın rolü yadsınamaz. Ana akım medyanın resmi ideoloji çerçevesinde şekillenmiş anlatılarla kamuoyu oluşturma çabası, farklı yorumlara, karşı belleklere kapalı, eleştirellikten uzak yapısı, geçmişin medya aracılığılla resmi anlatı doğrultusunda yeniden ve yeniden üretilmesini doğurmaktadır. Bu nedenle ana akım medya ve ticari sinema sistemin onaylanmasından yana yapımlar üretirken bağımsız yapımların varlığı ve bakış açıları son derece önem taşır. Doğru kabul edilene eleştirel yaklaşıp, itiraz edebildiği ölçüde, gerçeğin söylenenin, gösterilenin dışında bir yerlerde olabileceğini göstererek, daha özgür bir iletişim alanı yaratabilir.

Dijital teknolojideki gelişmelerle birlikte günümüz insanının yeni bilgilere ulaşıp, yeni durumlara uyum sağlaması, farklı kültürlerle karşılaşıp, diyalog kurması, hâkim ideolojilerin bilgi üzerindeki kontrollerinin kırılarak, toplumlarda demokratikleşme zemininin oluşmasını sağlamıştır. Dijital gelişmeler doğrultusunda, görsel işitsel kayıtların kitlelere ulaşabildiği alternatif olarak internetle birlikte görüntü ve ses, sınırsız çeşitlilikte depolanan ve erişilebilinen bilginin hem kaynağı hem aracı haline gelmiştir (Susam, 2015, s.173). Tarihi bir anın kayıtları anında dünyanın dört bir yanına ulaşabilmekte, tekrar ve tekrar izlenebilmekte, dijital arşivlerden çıkarak geçmişi hatırlama ve güncel bağlantılarla yeniden analizlerin nesnesi, farklı yapımların malzemesi olabilmektedir. Dijital teknoloji sayesinde, çok farklı coğrafyalardaki insanları tek bir ortak çıkar etrafında bir araya getirmek, belli bir konuda kamusal farkındalığı artırmak artık çok daha kolaydır. Teknolojideki hızı gelişme ile birlikte, insanların dünyanın farklı köşelerinden bağımsız, ilk ağızdan anlatılmış hikâyeleri dinleme ve görme talepleri kaçınılmaz olarak sinemayı da etkilemiştir. Bu bağlamda, günümüz belgesel anlatılarının hem teknolojik gelişmelerle hem de sosyal beklentilerle şekillendiğini söylemek pek de yanlış olmaz. Belgeseller ve dijital teknoloji arasındaki ilişki, belgesel kültürünün de değişmesini doğurmuştur. Coğrafi konumdan bağımsız olarak birbirine erişebilen geniş kitle bir belgesel anlatısının hem izleyicisi, hem yönetmeni, hem de bizzat konusu olabilmektedir. Belgesel anlatısı sosyal katılımın etkin bir arenası haline gelebilmektedir (Birchall, 2008, s. 278).

Bu çalışma temel olarak belgeseller üzerinde duracağından, türün ele aldığı konular, amaçları, bakış açısı ve yaklaşımları, yapıları, yapım özellikleri ve son olarak da izleyiciye sundukları çerçevesinde genel özelliklerine değinmek yerinde olur. Konuları açısından, belgesellerin, genel insani durumları ele aldığını, özellikle de bireysel eylemleri, ilişkileri, duyguları özelden genele varacak bir şekilde işlediğini söyleyebiliriz. Dolayısıyla da ele aldığı konular çerçevesinde amaç, bakış açısı ve yaklaşımları, kameranın karşısında var olanları izleyicide bir tavır oluşturmak ve etkilemek üzere kaydetmek ve aktarmak olarak öne çıkmaktadır. Bu noktada sosyal bir sorumluluk üstlenirler. Bu da belgesel yapısının, içeriği oluşturmaktan, kurmaktan çok, var olana dayanmasını doğurur. Bu yapı çerçevesinde de yapım özelliklerinde, gerçek kişiler, yerinde ve zamanında yapılmış çekimler, doğal aydınlatma, anlamı dönüştürmekten uzak bir kurgu temel olmaktadır. Bu özellikleri çerçevesinde de izleyiciye sundukları, eyleme geçmeye kadar uzanan bir çizgide sosyal bir tecrübedir (Ellis, McLane, 2005, s.1-3). 
Tarihi konular çerçevesinde ele aldığımızda, Carmen Guarini'nin, bellek filmleri üzerine ikili ayrımı oldukça tanımlayıcıdır; "belleği iletmek üzere yapılan filmler" ve "belleğin bir parçası olmak üzere yapılan filmler" (Aktaran Waterson, 2007, s.65). Kolektif bilince seslenmesi açısından belgesel, resmi tarih dışında bir bakış için kapı açıp, resmi tarihin sorgulanmasını sağlayabilir. Diplomasiden, siyasetten, sınırlardan, istatistikten öte, tarihi yaşayan, geçmişi oluşturan insanı, duygu ve düşünceleriyle ele alarak, böylelikle kişisel olanı öne çıkararak yaşananları daha insan merkezli anlamamızı sağlayabilir. En önemlisi de bu şekilde, önyargıları yıkabilir. Belgeseller, insanı insana yaklaştııırken var olan sorunların farklı gerçeklik zeminlerinde tartışıımasına, görülmesine yol açıp; kimi zaman yüzleşme ve hesaplaşma süreçlerinde oluşturdukları tartışma zeminiyle katalizörlük de yaparlar (Susam, 2015, s.38). Bir belgesel için yapılan çekimleri sadece ham malzeme, birer kayıt olarak ele aldığımızda dahi taşıdıkları belge niteliği belgesel yapımlarının tarih yazımı

Belgesel yapısının, içeriği oluşturmaktan, kurmaktan çok, var olana dayanması çerçevesinde de yapım özelliklerinde, gerçek kişiler, yerinde ve zamanında yapılmış çekimler, doğal aydınlatma, anlamı dönüştürmekten uzak bir kurgu kaçınılmaz olmaktadır. Belgeselin yerinde ve zamanındalık temeli, geçmişle ilgili konular ele alındığında daha problemli bir zemine taşınmaktadır. Belgeselin bir anlatım olması, gerçeğin, çok boyutluluğu çerçevesinde çeşitli yorumlama aşamalarından geçtiği göz önünde bulundurulmalıdır. Belgeselde ve onun toplumsal bağlamı dâhilinde bulunan farklı yorumlama katmanları şöyle sıralanabilir; belgeselcinin kameranın vizöründen yönelen asıl bakışı ve görüntüleri seçerek kurgulayarak oluşturduğu bakış; filmde yer alan kişilerin kendilerine asıl bakışları ve filmdeki kendilerine bakışları; izleyicinin filmde yer alan kişilere ve onlar üzerinden kendine bakışı. Belgeselcinin, filme konu kişilerin ve izleyicinin bu, farklı üç bakışı, belgesel gerçeğinde üç farklı yorum katmanı olarak ortaya çıkar.

Belgesellerin, genel insani durumları ele aldığını, özellikle de bireysel eylemleri, ilişkileri, duyguları özelden genele varacak bir şekilde işlediğini söylediğimizde, belgeselin mesajını en güçlü şekilde taşıyan unsur da filmin karakterleri olmaktadır. Karakterler, dolayısıyla da özdeşlik kurulabilecek insan hikâyeleri üzerine kurulmuş belgesellerin izleyici üzerindeki etkisi daha fazladır. İzleyici onlara ne olduğunu, hayatlarının nasıl değiştiğini, nasıl dönüştüklerini görmek istemekte, karakterlere merhamet duyarak ya da onlarla empati kurarak karakterlere dolayısıyla belgesele de bağlanmaktır (Cizek, 2005, s.80). Karakterler üzerine kurulmuş filmler açısından en az yaratıcı olan yöntem olarak görülen, konuşan kafalar olarak da adlandırılan röportajlar dahi bir iletişim kurma çabası olarak düşünüldüğünde değerlidir. Sadece bu iletişim niyeti bile belgeselin gücünü oluşturabilir. Belgesel görsellinde, konuşmacının kendi öz sunumuna dair taşıdığı izler, konuşma stili, ses tonu ve temposu, duraklamaları, tereddütleri, yüz ifadeleri, beden dili, jestleri, duygu ve düşüncelerine dair izler taşımaktadır. Dolayısıyla tarih çalışmaları çerçevesinde ele alındığında, belgesel geçmişin ve gerçeğin bizzat kendisi olmasa bile taşıdığı görsel işitsel bilgi göz ardı edilemez.

Filmin malzemelerinden öte yapım süreci de, konuya odaklanmanın belleği uyandırmadaki etkisi, herhangi bir film ekibi ya da kamera orada olmasa ortaya çıkmayacak eski davranışların yeniden keşfedilmesi ile tarihi kayıtların oluşturulmasında etkin olabilmektedir. Kamera röportaj yapılan kişinin anlatımını etkileyecek bir itici güç olarak değerlendirilebilir ancak bu noktada belleğin oyunları, karakterin sadece neyi nasıl hatırlamak istiyorsa öyle hatırlayabileceği de göz ardı edilmemelidir. Kamera önündeki kendi öz sunumunun kontrolünden öte, özellikle toplumlarda derin izler bırakmış travmatik tarihi olaylarla ilgili, Michael Ignatieff'in de belirttiği gibi, mağdur olduklarını düşünenlerin nesnelliklerini yitirebildiklerini, kendi sorumluluklarını ya da yaptıklarını görmezden gelebildiklerini, masumiyet ve mağduriyet mitlerinin istenmeyen gerçeklerle yüzleşmede bir engel oluşturabildiğini dikkate almak gerekir (Ignatieff, 1996). Dolayısıyla, bir belgesel yapımda kişilerin tanık olarak söyledikleri gerçeğin yerini tutamaz, ancak bu, çelişki ve eksik içerse de bu anlatıların önemsiz, değersiz olduğu anlamına da gelmez. Anlatmak, dile getirmek, bir hatırlatma formu olarak belleği yeniden şekillendiren bir eylem olarak değerlendirilmelidir (Susam, 2015, s.70). Üçüncü yorum katmanı olarak izleyici açısından sadece bu tanıklıkları dinlemek bile etkili olabilir, onu gördüklerine, duyduklarına, bildiklerine eleştirel yaklaşmaya itebilir.

\section{TARIH VE TOPLUMSAL BELLEK}

Tarih felsefesindeki gelişmelerle tarihin, gönderimselliğe, gerçekçiliğe ve heterojenliği baskılayan gerçeklere temellendirilen tekil, her şeyi bilen ve bir üst anlatı olarak kurulan yapısından, çok kültürlü, daha özelleştirilmiş, çoğul geçmişleri inşa eden bir yapıya kaydığı görülmektedir. Berkhofer bu çoğul geçmişleri çokseslilik olarak tanımlarken, farklı bakış açılarının, çelişkilerin, uzlaşmazlık ve ayrışmaların, tarihi analizleri farklı açıklayıcı biçimlere açtığını belirtir (Berkhofer, 1995, s.263-83). LeCompte de tarihin tarihi yazanlara ait olduğunu savunurken, modern tekniklerin de, ki film de bu modern tekniklerden biridir, tarih yazımında yetkin biçimler sağladığını belirtir (LeCompte, 1981, s.53). Dolayısıyla tarih bir kurgu, bir inşa olarak ele alındığında, belgesellerin de Susam'ın da belirttiği üzere bir yandan tarihe malzeme sunarken, bir yandan da tarihin yeniden yazımının aracı olduğunu söylemek yanlış olmaz (Susam, 2015, s.49). 
Tarihsel anlayış büyük ölçüde bellek üzerinden güvence altına alındığı için bellek de tarih arenası gibi önemli bir mücadele alanıdır (Walker, 1997, s.822). Unutmak ve/veya unutturmak, hatırlamak ve/veya hatıllatmak iktidarların bellek stratejileri olarak işleyebilmekte, bellek yeniden inşa edilip, yönlendirilebilmektedir, dolayısıyla kurgusaldır. Bellek bir unutma-hatırlama diyalektiğinin içinde anılarla taşınır (Huyssen, 1999, s.13). Her bir bireyin kendi anıları, tecrübeleri tek başına eşsiz olmakla birlikte, bakış açılarının çoğaltılması tarihi olayları daha iyi kavrayabilmemizi sağlayacaktır. Özellikle de genellikle kayıt dışı kalan, o tarihi olayları yaşayan sıradan insanların tecrübeleri o olayların nasıl hatırlanacağında büyük rol oynayacaktır. Tabi bu noktada bir bireyin tarihi bir olaya dair anısının toplumsal bellekte yer alabilmesi için tarihsel ve duygusal bir tepki uyandırıyor, görünüşte birbirinden ayrı olayları neden-sonuç ilişkisi içinde bütünlüyor olması gerekliliğini vurgulamak yerinde olur. Chirwa, toplumsal belleğin, bireysel ve toplumsal düzeyde uzlaşma, iyileşme ve yeniden yapılanmanın bir parçası olarak kabul edilmesi gerektiğini tam da buradan yola çıkarak açıklar. Çünkü toplumun bireyleri arasında oluşan duygusal dayanışma psikolojik bir terapi işlevi görmektedir (Chirwa, 1997, s.482). Belgeseller de bireysel belleğin kamusal alana taşınma zemini olarak bu çerçevede değerlendirildiğinde, sundukları tanıklıkların inanııılığı tartışııır olsa bile, o tanıklığın doğurduğu duygusal etki bile göz ardı edilemeyecek değerdedir. Özellikle de filmler içinden çıktıkları toplumlara geri döndüklerinde yarattıkları etki, kendilerinin yıllardır anlatmak, ifade etmek istedikleri ile karşılaşmaları sonucu, kamusal farkındalığın artması, güven kazanarak kendini daha güçlü hissetme ve örgütlenme olabilmektedir.

\subsection{Sırlar Dökülüyor; Türkiye Ermenistan Belgeselleri}

Türkiye sinema tarihine baktığımızda da, ana akım karşııında belgesel sinema, ağır sansür koşullarında ve ticari dolaşımın desteklerinden uzak, kendine bir yer bulmaya çalışmıştır. Özellikle 2000'lerle birlikte dijital teknolojinin yaygınlık kazanması, sayısı her geçen gün artan festivallerle, internetle farklı yapımlara ve beraberinde sinema yazınına ulaşabilme olanaklarının artması, dolayısıyla sinema okur-yazarlığının artması sonucunda sinema, özelde de belgeseller etkin bir ifade aracı olarak tercih edilmeye başlanmıştır. Böylelikle Türkiye sinemasında daha yerel, farklı dillerde, farklı kültürleri yansıtan, farklı ideolojilere dayanan, farklı kimlikleri temsil edebilen belgesellerin sayısı gün be gün artmıştır. Bu sinemanın kendine özgü koşullarındaki gelişmelerin yanı sıra, 2000'ler Türkiyesinin siyasi, sosyal, ekonomik ve kültürel yapılanışı ile de yakından alakalıdır.

Avrupa Birliği sürecinde ifade ve fikir özgürlüğü yolunda atılan adımlara paralel, genel olarak kimlik kavramına yönelik yoğun ilgi ve Hrant Dink gibi büyük bir bedel ödenmesi ile birlikte, siyasi ve entelektüel açılımın önemli bir ayağı Ermeni sorununa ve 1915'e dair anlatıların artarak çeşitlenmesi şeklinde kendini göstermiştir. Belgesel yapımların da dâhil olduğu pek çok anlatı, yıllarca sessizleştirilen yakın tarih hakkında bir konuşma girişimi olarak artan sayıda ortaya çıkmış, çıkmaktadır. Tabii ki bu sayısal artış belleğin sürekliliğini sağlamak adına 1915 'in 100 .yılının yaratıcı çalışmalara teşkil ettiği itici güç çerçevesinde de değerlendirilebilir. Türkiye'de 1915 'te yaşananlardan etkilenen ve Ermeni yaşamlarının izlerini taşıyan yerler, yaşamlar çok fazladır. Ana akım medyadaki tartışmalar büyük ölçüde uluslararası siyasi boyuta odaklanırken bu olayın Türkiye'de sıradan bireyler ve mekânlar üzerindeki etkisi çoğu zaman inmal edilmektedir (Neyzi, Kharatyan-Araqelyan, 2010, s.16). Soykııım odaklı hâkim anlayışın sorunsallaştııımaya başlanması ile geçmişle hesaplaşmayı, birbirini dinlemeyi ve anlamayı, uzlaşmayı dillendiren anlatılar her iki toplumun sinemasında da görülebilmektedir. Bu anlatılarda bireylerin, ailelerin hikâyeleri ile sorunun geniş ölçekli sosyo-politik tarihi el ele gitmektedir.

Ermeni sorunu ve 1915 'te yaşananların bugüne bıraktığı derin izlerin peşinden giden belgesellerin üretimindeki etkin kurumlardan biri de Ermenistan Türkiye Sinema Platformu'dur. Anadolu Kültür ve Uluslararası Altın Kayısı Film Festivali'nin, 2009 yılı Nisan ayında İstanbul'da bir toplantıyla kuruluşunu açıkladığı platform kapsamında atölyeler yapılmakta, kısa filmler ve belgeseller için fonlar sağlanmakta, her iki toplumun sinemacılarının birlikte film üretebilmeleri için olanaklar yaratılmaktadır. Platform varoluş esaslarını "Biz ortak paydası sinema olan Türkiyeliler ve Ermenistanlılarız. Sinemayı seviyoruz, sevmekle kalmıyoruz, sinemanın iyileştirici ve barıştırıcı gücüne inanıyoruz. Sinemayla birbirimize on yıllardır söyleyemediklerimizi söyleyebileceğimize, birbirimizi tanıyabileceğimize inanıyoruz. İnanmakla kalmıyoruz, bunu yapıyoruz!" şeklinde ifade etmektedir ${ }^{1}$.

Platformun 2012 projelerinden Diyar (Yön. Devrim Akkaya) ${ }^{2}$ suskunlukların üzerine giden filmlere önemli bir örnektir. Bir birinci şahıs belgeseli olarak yönetmen kendi ailesi içinde yaşananlara bakmakta, tamamen kişisel deneyimleri ile konuya yaklaşmaktadır. Akkaya, İstanbul'da oturan bir yoga eğitmenidir. Göç, çocuk ölümleri, cinayet ve reddedilme gibi travmaların gelecek kuşaklar üzerindeki etkilerini araştıran "aile dizimi" çalışmasına

\footnotetext{
${ }^{1}$ Platform hakkında detaylı bilgi için http://www.cinemaplatform.org

2 Diyar ile ilgili detaylı bilgi için https://www.facebook.com/pages/D\%C4\%B0YAR/411469228923786 ve http://diyar.ahestefilm.com/
} 
katıır. Aile dizimi yöntemi, ailenin kuşaklar boyu birbirine görünmez bir bağla, çok daha derinden bağlı olduğu anlayışına dayanır, kuşaklar öncesinde yaşanan bir tecrübenin bugüne yansıdığını, aktarıldığını hatta geçmişte giderilemeyen, tedavisinden kaçılan acıların yükünün bugüne devredildiğini iddia eder. Akkaya, bu çalışma sonrası, hissettiği yalnızlık ve aidiyetsizlik duygusu, kendi ailesini kurmak konusunda gösterdiği direncin nedenleri üzerine düşünürken 1915 'te evlat edinilmiş olan Ermeni büyük dedesi gelir aklına. Ailesiyle bunu paylaştı̆̆ında, büyük dedesi Yusuf'un mezarının kimsesizler mezarlığında, bilinmeyen bir yerde olduğunu öğrenir. Hem büyük dedesi Yusuf'un hikâyesinin hem de kayıp mezarının peşine düşer. Aile bireylerinin belleklerindekiler ile $\mathrm{O}$, tarihi olayları yaşayan sıradan insanın, Ermeni büyük dedenin hikâyesi o olayların, nasıl hatırlanacağını etkiler. Aileden bir bireyin büyük dedenin hatırası önünde bu saygıyla eğilme girişimi, bir yandan da tüm aile içinde unutma-hatırlama pratiklerinin nasıl işlediğini gözler önüne sermektedir. Konuşmakta ve mezarlığın izini sürmekte resmi tarihin beyinlerde oluşturduğu sınırlarla pek de istekli olmayan, dede ve akranı akrabalar karşısında yeni kuşaklar, baba, kardeşler ve Devrim Akkaya'nın kendisi kimlikleri ve tarihi gerçeklerin kendi aileleri üzerindeki izlerini sürmekte kararlıık gösterirler. Bu karakterlerle belgesel resmi tarihle bağdaşmasa da yakın tarihin yeniden değerlendirilmesine yönelik bir nitelik kazanır. Filmde, iletişimin temel araçlarından dil bile geçmişle bugün arasındaki kopukluğu sergileyen bir araç olarak simgesellik taşır. Kürtçe ve Türkçe konuşan ailede Ermenice, unutulmuş, hiç öğretilmemiş bir dil olarak büyük dedenin kimliğini nasıl yaşadığının izlerini bugüne taşır. Ermeni dedesinin acısı "geçmiş" bir acı değil, üç nesil sonra bugünü ve geleceği şekillendirmeye devam eden bir acıdır ve Kürt, Alevi bir aile olarak ülkedeki azınlık kimliklerinin pek çoğunu taşıyan bu aile özelinde farklı temsiliyetler de kazanarak, başka acıların ve suskunlukların da daha oluşmadan önlenmesine katkı sağlayabilir.

Kendisini “Ermeni, ABD'li ve Bitlisli bir yazar" olarak tanımlayan yazar William Saroyan'ın 1964 yılında Bitlis'e yaptığı yolculuğu konu alan, Saroyan Ülkesi (Yön. Lusin Dink) ${ }^{3}$ yine platformun 2011 yılında destek verdiği projelerdendir. Kırkdokuz yıl sonra Saroyan'ın yolculuğunun izinde, atalarının peşinden giden bir adamın kendisini bir kez daha keşfedişine tanıklık eden filmin yönetmeni Lusin Dink, filmle, Saroyan üzerinden insanların sorular sormasını amaçladığını belirtmektedir ${ }^{4} \mathrm{ki}$ tarihin yeniden yazımı da yeni sorulara bulunan cevaplarla mümkün olabilmektedir. Film yapım özelliği olarak belgeselin gerçekçi biçiminden uzaktır. Dolayısıyla film röportajlar, canlandırmalar ve tamamıyla yazarın eserlerinden kolajlanmış metinle kurgulanmıştır. Canlandırmalarda Saroyan'ın yüzünü hiçbir zaman görmeyiz, çoğu zaman gölgesini takip ederiz. Bu aynı zamanda ona bir temsiliyet de yüklemektedir. Lusin Dink, Saroyan'ın filmde göçmen olmuş, soykııımlar ve sürgünler yaşamış bütün insanları temsil ettiğini belirtmektedir. Filmin temel görsel unsurlarından araba da zaman açısından bir temsiliyet taşımaktadır. 1960'ların Chevrolet'i günümüzde Anadolu yollarında gezmektedir. Zamansızlığın bir sembolü olarak değerlendirilebilir. Tarihin içinden kopup gelmiş bu araba bir nesne olarak çıkıp geldiği dönemin tanığı olarak yazar ve yönetmenle birlikte iz sürmektedir. Bir zamanlar Bitlis'te Ermeniler yaşamış, 1964'te Saroyan onların izini ve kendini bulmak üzere bir yolculuğa çıkmış, 2011'de de Dink Saroyan'ın adımlarını takip etmiştir. Film, bu üç zamanı da iç içe geçirmektedir. Yönetmenin ve yazarın yolculuklarından ortak izler de zamanı bir kez daha iç içe geçirip, Anadolu topraklarında Ermeni kimliğinin nasıl yaşandığına dair çıkarsamalar yapmayı mümkün kılmaktadır. Lusin Dink Saroyan'ın gittiği birçok şehirde, diyelim adı Ayşe olan birisinin gelip Saroyan'ın kulağına 'Benim adım Sona aslında' diye fısıldayabildiğini, belgesel ekibinin de orada Saroyan'ın hikâyesini çektiğini öğrenen kişilerin orada hala Ermeni ailelerin yaşadığını söylediklerini belirtiyor. Çekimler için Bitlis'e gittiklerinde yanlarına gelen bir gencin 'Bir Ermeni arkadaşım var. Sizinle konuşmak istiyor' dediğini 'Nasıl yani, Bitlis'de hala Ermeni var mı?' diye sorduğunda da 'Var tabii. Arkadaşımın babası imam. Babası Ermeni olduğunu kabul etmiyor ama arkadaşım Ermeni kimliğine sahip çıkıyor. Bu yüzden sizinle tanışmayı çok istiyor' diye cevap verdiğini aktarıyor. Bu tecrübe belgesellerin tarihle olan ilişkisinde değindiğimiz üzere sadece yapım sürecinde, kameranın ve film ekibinin oradaki varlığıyla bile belleklerin uyanabildiğini, potansiyel tanıklıklar için sosyal bir alan yaratabildiğini göstermektedir.

Saroyan'ın orijinal metinlerinden kolajlanmış filmin metni de belgeselin bellek, tarih ilişkisi üzerinden bireysel anlatıların, üstlendiği önemli misyonu dile getirmektedir ki burada yine ikili olarak hem yazarın eserleri hem de belgeseli göz önünde tutmak gerekir. Filmin metninde yazar anne babasının anlattıklarından özlem içinde bahsederken, "atalarımızın belleklerinin gittiği yere kadar" kişisel tarihlerini aktarabildiklerini belirtmektedir. Dolayısıyla yine yazarın kendi yazılarını "sadece kayda geçiriyorum, insanlara bildiklerini anlatıyorum" diye yorumlaması belleğin kayıt altına alınarak nesiller boyu taşınabilirliğini ve görünürlüğünü sağlamak olarak değerlendirilebilir. Aynı şey tabi ki belgeselin kendisi içinde söz konusudur. Saroyan ve Dink belleğin tarih

\footnotetext{
${ }^{3}$ Saroyan Ülkesi ile ilgili detaylı bilgi için http://www.narfilm.com/new-page-2/ ve https://tr-tr.facebook.com/pages/Saroyan\%C3\%9Clkesi/582045871808391

4 Yönetmen Lusin Dink'le yapılmış röportajlar için http://bianet.org/biamag/toplum/152422-saroyan-ulkesi-ile-saroyanyolculugu ve http://www.malatyahaber.com/haber/zamansiz-acilarin-oykusu
} 
içindeki önemini göz önünde tutarken, öznelliğini de göz ardı etmemektedirler. Yine filmin metninde yer alan sözleriyle Saroyan "Hafıza acı, yoksunluk ve inkârla oluşur. 3 yaşında annenden ayrılıp küf kokulu yetimhaneye gittinde hafıza başlar. Hafıza hayal gücüdür, çünkü gördüklerin ve hatırladıkların asla olanın kendisi değildir. Esas olan tüm bu olanların sende nasıl anlamlandığıdır." der.

Belgesellerin, yapım süreci ve kendisi kadar, gösterimlerinin de izleyici üzerinde yarattıkları etki çerçevesinde tarih yazımına katkıda bulunduğu söylenebilir. Belgeseller özellikle içinden çıktıkları toplumlarda izleyici ile buluştuğunda kendilerinin yıllardır anlatmak, ifade etmek istedikleri ile karşılaşmaları sonucu, kamusal farkındalığın artmasını, güven kazanarak kendini daha güçlü hissetmeyi ve örgütlenmeyi sağlayabilmektedir. Herhangi bir izleyicinin sadece tanıklıkları dinlemesi, tanıklarla karşılaşması bile onu gördüklerine, duyduklarına, bildiklerine eleştirel yaklaşmaya itebilir. Gösterimler sonrasında, söyleşilerde kurulan yüz yüze iletişim, online gösterim sayfalarında ve sosyal medyada yer alan izleyici yorumları bizzat süregiden bellek oluşumunun bir parçası haline gelmektedir. Filmler yeni filmlere ilham vermekte, farklı bireyler kendi ailelerine bakmakta, film bir zincirleme reaksiyonun tetikleyicisi olmaktadır. Diyar'ın 16 Nisan 2014'de İstanbul Film Festivali'ndeki, bizzat aile üyelerinin de katıldığı gösterimi sonrası Facebook sayfasına gelen izleyici yorumları bu etkiyi açıkça gözler önüne sermektedir ${ }^{5}$.

Saroyan Ülkesi'nde olduğu gibi terkedilmiş, kaybedilmiş yurdu görmek üzere yapılan yolculukların hikâyesini anlatan filmlerden biri de platformun 2010 projesi Kunduralarımı İstanbul'da Bıraktım (Yön. Nigol Bezjian) ${ }^{6}$ belgeselidir. Belgesel, şair Sako Arian'ın, bir yüzyıl kadar önce atalarının terk etmek zorunda kaldığı İstanbul'a biraz korkuyla ama artık önüne geçemediği bir özlemle yaptığı bir yolculuğu takip etmektedir. Arian, kuşaklar boyu dinlediği ve bir zamanlar Ermenilerin yaşadığı İstanbul sokaklarını, eski mezarlıkları ve orada yatan şairleri, eski kiliseleri, liseleri turlar. Genç, yaşlı, Türk, Ermeni onlarca kişiyle karşılaşıp, yemeklerine ve sohbetlerine ortak olur. Onlarla güler, onlarla hatılar. Böylelikle bizzat belgesel, Arian İstanbul'a gelmek konusunda tereddüt gösterdiğinde arkadaşının dediği gibi, yaralarını iyileştirmek için araç olur. Lusin Dink gibi Bezjian'ın da direkt bir mesaj vermek üzere değil, sadece cevap bekleyen soruları paylaşmak üzere yaptığını söylediği filmin, İstanbul'daki gösterimi Ermeni, Türk, Kürt, Alevi, 650 kişilik bir salonda gerçekleşmiştir? . Böylelikle filmde yer alan röportajlardan birinde bir gencin "Ermenilik sadece soykırımla ilgili değildir. Biz gençler Türklerle Ermeniler arasındaki duvarları yıkmalıyız." şeklinde ifade ettiği üzere toplumlar bizzat o salonda diyalog kurmaya başlamışlardır. Arian ziyaret ettiği Ermeni Kültürü ve Dayanışma Derneği'nde, derneğin etkinliklerine, Ermenice derslerine gelenlerin genelde Ermeni olmadığını öğrenir. Dernektekiler bunu 2007 sonrasının etkisi olarak değerlendirmekte ${ }^{8}$, bunu toplumlararası diyalogun kurulmasında üstlerine düşen görevi yerine getirebilmeleri olarak yorumlamaktadırlar.

Polemikler üretmeden, açıklama çabasına düşmeden, tartışmadan ve yargılamadan, sadece geçmişte yaşananların, onları yaşayanlar için nasıl olduğuna dair bir his uyandırmak üzere yapılan filmlere bir örnek de platformun 2014 projelerinden Bizim Atlantis'imiz (Yön. Arthur Sukiasyan) ${ }^{9}$ belgeselidir. Belgesele konu olan Ermeni Çocuk Kampı, 1960'larda Tuzla'da çocuklar tarafından inşa edilmiştir. Bu, azınlık kültürünün ve dininin sürdürülmesi amacıyla kurulmuş, kampa bir süre sonra devlet politik nedenlerle el koyar. Seneler sonra, bu kampta yıllarını geçirmiş, insanlar burayı geri alma çabasıyla bir araya gelir. Eski kamp sakinlerinin siyah-beyaz fotoğrafları eşliğinde, titrek seslerinden ve buğulu gözlerinden dinlediğimiz hikâyeleri daha büyük bir hikâyenin

\footnotetext{
5 https://www.facebook.com/pages/D\%C4\%BOYAR/411469228923786, 17 Nisan 2014 tarihli yorumlar; Gül Dirican: "Devrim Akkaya'nın Diyar belgeseli, yüzyılbaşında nüfusunun yarısı ermeni olan bölgede unutmanın imkansızlığı... Geçmişin şifası için güçlü bir adım, tebrikler.", Hande Tarıman: "Şahaneydi. Köklerim beni çağırıyor şu anda. Başta siz ve dedeniz olmak üzere herkesin yüreğine sağlık.", Ayşe Akbal Baysal: "Samimiyeti ve anlatımı ile harikaydı Diyar, eline sağlık, emeğinize sağlık... Salondan çıkamayan biz seyirciler ailenin hikayesinin yanı başında olmaktan çok heyecan duyduk ve köklerimize gitmeye ilham aldık.", Melek Ulagay Taylan: "Yanımda çok sevdiğim bir Ermeni ile izledim, filmi izlerken bir yandan da onu izledim. İçimden Devrim'e seslendim, işte hep düşlediğimiz anı yaşıyoruz."
}

6 Kunduralarımı İstanbul'da Bıraktım ile ilgili detaylı bilgi için http://www.cinemaplatform.org/tr/filmler/kunduralarimiistanbulda-biraktim/138 ve http://www.thinkplustv.com/index.html

${ }^{7}$ Nigol Bezjian ile yapılan röportajlar için http://armenianweekly.com/2013/04/06/film-about-armenian-istanbul-premieresin-turkey/ ve http://www.accc.org.uk/old-istanbul-at-the-golden-apricot-film-festival/

8 Agos gazetesinin Ermeni asıllı genel yayın yönetmeni Hrant Dink, 19 Ocak 2007 tarihinde, gazete binasının önünde öldürüldü. Dink'in cenazesinde on binler cinayete tepki olarak "Hepimiz Hrant'ız, hepimiz Ermeniyiz" sloganları attılar.

9 Bizim Atlantis'imiz ile ilgili detaylı bilgi için http://www.cinemaplatform.org/en/films/our-atlantis/155 ve https://www.facebook.com/ouratlantisthefilm/info 
gözler önüne serilmesini sağlar. Sukiasyan'ın "soykırım hakkında değil trajedinin sonuçları hakkında" 10 diye tanımladığı film, savunmacı bir tavırla, bir azınlık cemaatinde yetişmenin ne anlama geldiğini hissettirmektedir. Filmde kullanılan eski fotoğraflar ve onları gösteren film karakterlerinin birlikte görüntüleri izleyicinin bakışı ile buluştuğunda tanıklığın sürekliliğini sağlamada etkin bir araç halini almaktadır. Saroyan Ülkesi'nde eski zamanlardan kalmış arabanın geçmişin tanıklığını bugüne taşıyan bir nesne olarak üstlendiği görevi burada eski fotoğraflar üstlenmektedir.

\section{SONUÇ}

Hâkim ideoloji tarih yazımını da belirlemekte, hâkim ideoloji doğrultusunda oluşturulan medya anlatıları da tarihi bilginin pekiştirilmesinde önemli bir rol oynamaktadır. Günümüz dijital teknolojisi ile birlikte ana akım medya anlatılarına alternatif anlatıların yapım ve izleyici ile buluşma olanaklarının artması, küçük, kişisel anlatıların büyük, resmi ve tarihi anlatılara karşı yer alabilmesini doğurmuştur. Ses ve görüntü kaydının kazandığı yaygınlıkla film belleğin etkili bir taşıyıcısı olarak tarihi değer de kazanmıştır. Böylelikle de tarihi konularda, resmi tarih karşısında hatırlatmalarda bulunmak ve toplumsal belleğe katkıda bulunmak adına bu kayıtları kullanan belgeseller de önemli bir noktaya gelmiştir. Belgeseller, bireylerin hikâyeleri ile özelden genele bir anlatım doğrultusunda, tarihe dair de önemli notlar düşmekte, sırları açık etmekte, kabul görmüş doğrulara dair soru işaretleri uyandırabilmektedir. Ayrıca karşı karşıya gelmemiş ötekiler birbirlerine böylelikle kulak vermekte, tanıklıklar tanışıklıkları güçlendirmekte, kültürler arası diyaloğu dolayımlı dahi olsa arttırmaktadır. Belgesel anlatısında gerçeğin yeniden sunumu, bireysel anlatımların öznelliği gözetilmek kaydıyla tanıklıklar çerçevesinde ortaya çıkan yeni yorumlar, bilgiler toplumsal bellekte yer edindikçe tarihin farklı yorumlarına katkıda bulunması mümkün olabilmektedir.

Türkiye Ermenistan ilişkileri özelinde tarih ele alınırken, kısır bir nefret söyleminden uzak, bireysel hikâyelerle, söylenemeyenleri söyleyen, kültürlerin birbirini tanımasına kapı açan belgesellerin taşıdığı potansiyel önemlidir. Toplumlar arasında uzlaşma zemininin sağlanmasında siyasi aktörlerin yanı sıra bireyler farklı iletişim kanallarına sahip olabilmeli, belgeseller de bellek oluşturma imkânları sunan bir alternatif olarak değerlendirilmelidir. Karşılıklı travmalar ve hatıralarla dolu bellekleri çatıştırmadan yeniden bir arada barış içinde yaşamanın olanaklarının tartışıması ancak tarihle yaratıcı yollarla yüzleşmekle mümkün olabilir. Böylelikle siyasi iktidarların unutmak ve/veya unutturmak, hatırlamak ve/veya hatırlatmak bellek stratejileri ile sırlanmış tarihin sırları da dökülebilir.

Bireysel belleklerin kamusallık kazanabilmesi için aktarılması gereklidir. Toplumsal belleğin akışına dâhil olduktan sonra zamana karşı dayanması ve geçmişin farklı yorumlarına katkı sağlaması mümkün olabilmektedir. Örneklerle de görüldüğü üzere, belgeseller işte bu nedenle de geçmişin unutulması karşısındaki önemli bir çaba olarak değerlendirilmelidir. Her bir yeni belgesel, yeni filmlere ilham vermekte, bireyler kendi ailelerine bakarak, sırlarını dökerek, toplumu, tarihi olayların farklı anlamları üzerine düşünmeye zorlamaktadır. Bu noktada belgeselci ve filme konu karakterlerden öte izleyiciler de kendi paylarına düşen sorumluluğu üstlenerek eleştirellikle, empati kurarak, sadece izleme edimiyle gerçekleştirdiği tarihi tanıklığın, süregiden bellek oluşumunun bir parçası haline gelmesini ve geçmişin yeniden ve yeniden değerlendirilmesini sağlayabilir.

\section{KAYNAKÇA}

Berkhofer, R. F. (1997). Beyond the Great Story: History as Text and Discourse. Harvard University Press.

Birchall, D. (2008). Online Documentary. Thomas Austin, Wilma de Jong(Ed.), Rethinking Documentary: New Perspectives, New Practices içinde. Maidenhead/New York: McGraw Hill, 278-84.

Chirwa, W. (1997). "Collective Memory and The Process of Reconciliation and Reconstruction". Development in Practice. 7:4, 479-482,

Cizek, K. (2005). "Storytelling for Advocacy: Conceptualization and Preproduction". Video for Change: A Guide for Advocacy and Activism, 74-121.

Ellis J. C., McLane B. A. (2005). A New History of Documentary Film. Continuum International Publishing Group.

\footnotetext{
10 Arthur Sukiasyan ile yapılan röportajlar için http://armenpress.am/eng/news/782545/our-atlantis-movie-sums-upmemories-and-pain-of-students-of-armenian-camp-in-istanbul.html
} 
Huyssen A. (1999). Alacakaranlık Anıları. İstanbul: Metis Yayınları.

Ignatieff, M. (1996). "Articles of Faith". http://archive.niza.nl/uk/publications/001/ignatieff.htm

LeCompte, E. (1981). "Who Owns History?". Performıng Arts Journal. Vol. 6. No. 1. 50-53.

Neyzi, L., Kharatyan-Araqelyan, H. (2010). Birbirimizle Konuşmak: Türkiye ve Ermenistan'da Kişisel Bellek Anlatıları. DVV International.

Susam, A. (2015). Toplumsal Bellek ve Belgesel Sinema. İstanbul: Ayrıntı Yayınları.

Walker, J. (1997). T"he Traumatic Paradox: Documentary Films, Historical Fictions, and Cataclysmic Past Events". Signs. Vol. 22, No. 4, 803-825.

Waterson, R. (2007). "Trajectories of Memory: Documentary Film and the Transmission of Testimony". History and Anthropology. 18:1, 51-73. 